\title{
Camp Century basal sediment revisited: a multi-parameter geochemical analysis, northwest Greenland
}

ANDREW J. Christ ${ }^{1 *}$, NiCOLAS PERdRIAL ${ }^{1}$, PAUl R. BIERMAN $^{1}$, JOHN HuGHES ${ }^{1}$, PAUl C. KNUTZ ${ }^{2}$, TONNY B. THOMSEN $^{2}$, SIDNEY HEMMING ${ }^{3}$, JULIE C. FOSDICK ${ }^{4}$, DORTHE DAHL-JENSEN ${ }^{5}$, JøRGEN P. STEFFENSEN ${ }^{5}$

${ }^{1}$ Department of Geology, University of Vermont, Burlington, VT, USA (*correspondence: Andrew.Christ@uvm.edu)

${ }^{2}$ Geophysics Department, Geological Survey of Denmark and Greenland, Copenhagen, Denmark

${ }^{3}$ Department of Earth and Environmental Sciences, Columbia University,New York, NY, USA

${ }^{4}$ Department of Geosciences, University of Connecticut, Storrs, CT, USA

${ }^{5}$ Centre for Ice and Climate, Niels Bohr Institute, University of Copenhagen, Copenhagen, Denmark

The Camp Century ice core was the first ice core drilled to the bed of the Greenland Ice Sheet (GrIS) and, in the 1970s, reshaped our understanding of Earth's past climate. The basal sediment was incompletely investigated, and remained in storage for decades until this year. Here, we report multi-parameter geochemical analyses of the basal sediment to characterize the mineralogy and sediment provenance and infer paleoclimate. XRD and SEM/EDS analyses suggest the fine fraction is dominated by quartz and feldspars with evidence of 2:1 clay weathering products. Single-crystal XRD analyses have so far characterized amphibole, clinopyroxene, orthopyroxene and garnet. Automated quantitative mineralogy results indicate that metamorphic minerals are present in sufficient amounts (100's) to gaining statistically valid provenance data. Preliminary results show ages in the $1.7-1.9 \mathrm{Ga}$ range (amphibole, rutile) and around $2.7 \mathrm{Ga}$ (zircon). This, along with the presence of swelling clays in the sediments, is consistent with weathering of the local bedrock, and/or sediments transported from the Inglefield orogenic belt north of the site. Similarly, ${ }^{40} \mathrm{Ar} /{ }^{39} \mathrm{Ar}$ ages of 45 hornblende grains primarily range between 1.7 and $1.97 \mathrm{Ga}$. (U-Th-Sm)/He ages of 35 apatite grains yield ages between 215 and $1105 \mathrm{Ma}$, with major age clusters centered at $227 \mathrm{Ma}, 269 \mathrm{Ma}$, and 337 $\mathrm{Ma}$, and suggest that sediment was not sourced from regions of rapid, deep glacial incision. We discuss the implications for understanding erosional processes, potential transport pathways, and paleoclimate implications of the Camp Century basal ice sediments. 